\title{
Effect of Changes in Zinc and Phytic Acid Content in Maize under Various Processes on Bioavailability of Zinc
}

\author{
Jati Heleena* and Singh Usha \\ Department of Food and Nutrition, College of Community Science, Dr. Rajendra Prasad \\ Central Agricultural University, Pusa (Samastipur) 848125, India \\ *Corresponding author
}

\section{A B S T R A C T}

\begin{tabular}{|l|}
\hline Ke y w or d s \\
Zinc, Phytic acid, \\
Maize, Processing, \\
Bioavailability \\
\hline Article Info \\
\hline Accepted: \\
17 November 2018 \\
Available Online: \\
10 December 2018 \\
\hline
\end{tabular}

\section{Introduction}

Maize (Zea mays L.) "Queen of cereal" is one of the most important cereals of the world and provides more human food than any other cereals. It is the third most important crop after rice and wheat cultivated in the world. It provides nutrients for humans and animals and serves as a basic raw material for the production of starch, oil, protein, alcoholic beverages, food sweetners and more recently fuel. Generally, maize is consumed in human food in the form of roti, sattu, dalia etc. prepared from maize after application of processing methods like drying and roasting. In India, over 85 percent of the maize production is used as food. The major part of maize as human food is being consumed as roti from flour which is prepared by grinding raw/roasted maize.

Maize is a staple human food eaten by more than a billion people around the world in a variety of whole and processed form of products. Different processing methods result in changes to the nutritional profile of maize products, which can greatly affect the micronutrient intake of population dependent on this crop for a large proportion of their caloric needs. Mineral bioavailability can be improved by processing methods to reduce phytic acids, such as soaking, fermenting, cooking and Nixtamalization. Losses of micronutrients during processing can be 
mitigated by changes in methods of processing, in addition to encouraging consumption of whole-grain maize products over degermed, refined products (Suri et al., 2016).

Zinc is an essential component of a large number $(>300)$ of enzymes participating in the synthesis and degradation of carbohydrates, lipids, proteins, and nucleic acids as well as in the metabolism of other micronutrients. Zinc stabilises the molecular structure of cellular components and membranes and contributes in this way to the maintenance of cell and organ integrity. Zinc is present in all body tissues and fluids. The total body Zinc content has been estimated to be $30 \mathrm{mmol}(2 \mathrm{~g})$. Skeletal muscle accounts for approximately 60 percent of the total body content and bone mass, with a Zinc concentration of 1.5-3 $\mathrm{mmol} / \mathrm{g}(100-200 \mathrm{mg} / \mathrm{g})$, for approximately 30 percent. Zinc concentration of lean body mass is approximately $0.46 \mathrm{mmol} / \mathrm{g}(30 \mathrm{mg} / \mathrm{g})$. Plasma Zinc has a rapid turnover rate and it represents only about 0.1 percent of total body Zinc content. This level appears to be under close homeostatic control. High concentrations of Zinc are found in the choroid of the eye $4.2 \mathrm{mmol} / \mathrm{g}(274 \mu \mathrm{g} / \mathrm{g})$ and in prostatic fluids $4.6-7.7 \mathrm{mmol} / \mathrm{l}(300-500$ mg/l) (Hambidge, 1987). Phytic acid or myoinositol hexaphosphate is a strong chelator of multivalent metal ions, especially iron, zinc and calcium (Hurrell, 2004).

For many years, Phytic Acid was considered an antinutritional compound because it reduces the bioavailability of several minerals important for human nutrition (Bhon et al., 2007) (Li et al., 2008) (Schlemmer et al., 2009). A study on determination of Phytate, iron, zinc, calcium contents and their molar ratios in commonly consumed raw and prepared food in Malaysia. The inhibitory effect of phytate on the bioavailability of iron, zinc and calcium was determined by measuring their molar ratios. The phytate content was analysed using Anion-exchange Chromatography whereas mineral contents were analysed using Atomic Absorption Spectrophotometer (AAS). In general, the results showed that cooked products have lower content of phytate and minerals as compared to raw products. This could be due to the influence of the cooking method on phytate and mineral content of food. The results showed that many of the food samples analysed had high phytate content which may impair the bioavailability of the mineral in the body (Norhaizan et al., 2009). Hence, the present study had been undertaken to study the effect of changes in zinc and phytic acid content in maize under various processes on bioavailability of zinc.

\section{Materials and Methods}

\section{Materials}

\section{Selection of raw materials}

Among the varieties, the most common normal maize being cultivated, 'Pioneer3522'was selected for the study.

\section{Procurement of maize grains}

For the study freshly harvested maize variety; (Pioneer3522) was collected from the farmers of Birauli, Samastipur in one lot. The quantity to be procured was $12 \mathrm{~kg}$. The collected maize grains were cleaned by isolating damaged and unhealthy seeds and remaining foreign matter. The remaining maize grains were 10 kilogram. The lot was divided into four equal sets in triplicate for processing. Each replicate of maize grains was of $2.5 \mathrm{~kg}$.

\section{Processing of maize grains}

For the study, out of four sets (in triplicate), one set was kept as such as control (in 
triplicate). The other three sets (each in triplicate) were kept for processing. The processing methods applied were boiling, roasting and alkali processing.

\section{Application of boiling method for maize grains}

Maize grains (in triplicate) were boiled in double amount of water by weight for 30 minutes. Then it was oven dried for 10 hours at $60^{\circ} \mathrm{C}$.

\section{Application of roasting method for maize grains}

Maize grains were roasted at $180^{\circ} \mathrm{C}$ for 20 minutes.

\section{Application of alkali processing for maize grains}

Maize grains were soaked for 5 minutes in double the amount of $1 \%$ lime water by weight and then heat treatment was given for 30 minutes at $85^{\circ} \mathrm{C}$. Then, it was kept overnight. Next day, the grains were washed 4 times and kept in oven for 10 hours at $60^{\circ} \mathrm{C}$ for drying.

\section{Methods}

\section{Determination of zinc}

The zinc was determined by using Atomic Absorption Spectrophotometer (AAS) (Lindsay and Norvell, 1978). 0.5g of flour sample was weighed and taken in $100 \mathrm{ml}$ conical flask. $10 \mathrm{ml}$ diacid was added and left over night. Then it was kept on a hot plate and heated gently. Then it was heated vigorously till a colourless solution was obtained. The heating was discontinued when the volume was reduced to $1 \mathrm{ml}$ (1 Drop). Precaution was taken not to take up to dryness. Then it was cooled and some distilled water was added.
Then it was transferred into a $50 \mathrm{ml}$ volumetric flask. The volume was made by adding distilled water. The reading was taken by AAS.

\section{Calculation}

$\mathrm{Zn}$ in grain $(\mathrm{ppm})=\mathrm{x} \times$ dilution factor

( $\mathrm{x}=$ reading noted from AAS)

Dilution Factor $=50 / 0.5=100$

$\mathrm{Zn}(\mathrm{ppm})=\mathrm{x} \times 100$

\section{Determination of phytic acid}

The phytic acid was determined by using the procedure that involves the use of spectrophotometer (Davies and Reid, 1979). $0.5-1 \mathrm{~g}$ of maize flour was taken. It was extracted with $20 \mathrm{ml}, 0.5 \mathrm{M}-\mathrm{HNO}_{3}$ for $3-4$ hours with continuous shaking. Then it was filtered. 0.2 to $0.5 \mathrm{~g}$ of filterate that was extracted was made upto suitable volume with water $(20 \mathrm{ml})$. To $1.4 \mathrm{ml}$ of the filterate, $1 \mathrm{ml}$ of Ferric Ammonium Sulphate solution (21.6 $\mathrm{mg}$ in $100 \mathrm{ml}$ water) was added, mixed and placed in a boiling water- bath for 20 minutes. The contents were cooled and $5 \mathrm{ml}$ of isoamyl alcohol was added and mixed. To this, $0.1 \mathrm{ml}$ ammonia solution was added, shaken thoroughly and centrifuged at $3000 \mathrm{rpm}$ for 10 minutes. The alcoholic layer was separated and the colour intensity was read at $465 \mathrm{~nm}$ against amyl alcohol blank after 15 minutes. Sodium phytate standards were run along with the sample. The results were expressed as $\mathrm{mg}$ Phytic acid/100g dry weight.

\section{Evaluation of bio-availability of Zinc}

For the determination of the bio-availability of zinc, the phytate: zinc molar ratio was calculated (Sandstorm, 1997).The mole of phytate and zinc was determined by dividing the weight of phytate and zinc $(\mathrm{mg} / 100 \mathrm{~g})$ with its atomic weight (phytate: 660g/mol; $\mathrm{Zn}$ : $65 \mathrm{~g} / \mathrm{mol})$. The molar ratio between phytate 
and zinc was obtained by dividing the mole of phytate with the mole of zinc.

Phytate/ zinc molar ratios

- Greater than 5: low zinc bio-availability

- Between 5-15: medium zinc bioavailability

- Less than 5: relatively good zinc bioavailability

\section{Statistical analysis}

The data obtained upon the determination of quality parameters of maize flours had been analysed for statistical implications by using Mean, Standard Deviation and Paired ' $t$ ' test to find out the effect of processing methods on the bio-availability of zinc in different maize varieties (Snedecor and Cohran, 1989).

\section{Results and Discussion}

\section{Zinc and phytic acid in freshly harvested maize before and after processing}

The Zinc in maize flour (control and after processing) was determined. The data obtained on Zinc in flour had quantitative changes after the application of different processing methods have been presented in Table 1 and 2.

The Zinc in maize flour from freshly harvested maize grains before and after processing methods like boiling, roasting and alkali processing has been presented in Table 1. The freshly harvested maize grains i.e., raw maize grains had been taken as control. It was revealed from the table that control flour sample contained $4.53 \mathrm{mg} / 100 \mathrm{~g}$ Zinc. In boiled maize flour sample, the Zinc content was $3.25 \mathrm{mg} / 100 \mathrm{~g}$. Roasted Maize sample contained $4.86 \mathrm{mg} / 100 \mathrm{~g}$ Zinc. In alkali treated maize flour sample, the Zinc content was 4.60 $\mathrm{mg} / 100 \mathrm{~g}$.
It can be observed in Table 1 that the Zinc content in roasted maize sample was the highest $(4.86 \mathrm{mg} / 100 \mathrm{~g})$ followed by the alkali treated maize sample $(4.60 \mathrm{mg} / 100 \mathrm{~g})$, control maize sample $(4.53 \mathrm{mg} / 100 \mathrm{~g})$ and boiled sample $(3.25 \mathrm{mg} / 100 \mathrm{~g})$.

The statistical analysis clearly shows that the Zinc content of the control maize sample was significantly higher than boiled maize sample (' $t$ ' value 15.43) at $1 \%$ level of probability. The Zinc content of control maize sample was significantly lower than roasted maize sample (' $t$ ' value -4.75 ) at $1 \%$ level of probability and the increase in the Zinc content of the alkali treated maize sample as compared to the control maize sample was not significant. Further, the Zinc content of boiled maize sample was significantly lower than the roasted maize sample ('t' value -42.34) and alkali treated sample (' $t$ ' value -17.35) at $1 \%$ level of probability. Whereas, the Zinc content of the roasted maize sample was significantly higher than the alkali treated maize sample (' $\mathrm{t}$ ' value 5.52 ) at $1 \%$ level of probability.

The phytic acid in maize flour (control and after processing) was determined. The data obtained on phytic acid in flour had quantitative changes after the application of different processing methods have been presented in Table 1 and 2.

The phytic acid in maize flour from freshly harvested maize grains before and after processing methods like boiling, roasting and alkali processing has been presented in Table 3. The freshly harvested maize grains i.e., raw maize grains had been taken as control. It was revealed from the table that control flour sample contained $233.01 \mathrm{mg} / 100 \mathrm{~g}$ phytic acid. In boiled maize flour sample, the phytate content was $202.23 \mathrm{mg} / 100 \mathrm{~g}$. Roasted Maize sample contained $210.95 \mathrm{mg} / 100 \mathrm{~g}$ phytate. In alkali treated maize flour sample, the phytic acid content was $206.71 \mathrm{mg} / 100 \mathrm{~g}$. 
It can be observed in Table 1 that the phytic acid content in the control maize sample was the highest $(233.01 \mathrm{mg} / 100 \mathrm{~g})$ followed by the roasted maize sample $(210.95 \mathrm{mg} / 100 \mathrm{~g})$, lime treated maize sample $(206.71 \mathrm{mg} / 100 \mathrm{~g})$ and boiled maize sample $(202.23 \mathrm{mg} / 100 \mathrm{~g})$.

The statistical analysis clearly shows that the phytic acid content of the control maize sample was significantly higher than boiled maize sample ('t' value 49.44), roasted maize sample (' $\mathrm{t}$ ' value 46.85) and alkali treated maize sample ('t' value 54.21) at $1 \%$ level of probability. Further, the phytic acid content of boiled maize sample was significantly lower than the roasted maize sample (' $t$ ' value 23.06) and alkali treated sample ('t' value 10.14 ) at $1 \%$ level of probability. Whereas, the phytic acid content of the roasted maize sample was significantly higher than the alkali treated maize sample (' $t$ ' value 7.54) at $1 \%$ level of probability.

Changes in zinc and phytic acid content of Maize after processing as compared to control sample

The changes in Zinc and Phytic acid content of Maize after application of different processing methods as compared to control sample can be observed in Table 2 and Figure 1. The maximum percentage loss in Zinc content was 28.25 percent in case of boiled maize sample. The maximum percentage increase in Zinc content was 7.28 percent in the case of roasted maize sample followed by 1.54 percent in case of alkali treated maize sample.

The maximum percentage loss in phytic acid content was 13.20percentin case of boiled maize sample followed by 11.28 percent in alkali treated maize sample and 9.46 percent in roasted maize sample.

It can be concluded from Table 2 and Figure 1 that after processing the changes in Zinc content was significant. In case of boiled maize sample, the Zinc content significantly reduced. In case of roasted and alkali treated maize samples, the Zinc content significantly increased. Definitely qualitative and quantitative changes occur after processing.

The changes in Phytic acid content were also significant. In case of boiled maize sample, the Phytic acid content significantly reduced followed by alkali treated maize sample and roasted maize sample. Definitely qualitative and quantitative changes occur after processing.

\section{Bio-availability of zinc in normal maize flour before and after processing}

The Phytate: Zinc molar ratio in Maize (control and after processing) was calculated. The mole of Phytate and Zinc was determined by dividing the weight of Phytate and Zinc $(\mathrm{mg} / 100 \mathrm{~g})$ with its atomic weight (Phytate: $660 \mathrm{~g} / \mathrm{mol}$; Zinc: $65 \mathrm{~g} / \mathrm{mol})$. The molar ratio between Phytate and Zinc was obtained by dividing the mole of Phytate with the mole of Zinc.

If the Phytate: Zinc molar ratio was greater than 5, there was low Zinc bioavailability. If it was between 5-15, then there was medium Zinc bioavailability, if it was less than 5, there was relatively good Zinc bioavailability. The bioavailability of Zinc in the maize before and after processing has been presented in Table 3.

The phytate: zinc molar ratio in maize flour (control and after processing) was calculated and this helped us to evaluate the bioavailability of Zinc in maize grains before and after the application of different processing methods like boiling, roasting and lime treatment which has been presented in Table 3. 
Table.1 Level of zinc and phytic acid in freshly harvested maize before and after processing

\begin{tabular}{lcc}
\hline $\begin{array}{l}\text { Maize grain } \\
\text { Sample }\end{array}$ & $\begin{array}{c}\text { ZINC } \\
(\mathbf{m g} / \mathbf{1 0 0} \mathbf{g})\end{array}$ & $\begin{array}{l}\text { PHYTIC ACID } \\
(\mathbf{m g} / \mathbf{1 0 0 g})\end{array}$ \\
\hline Control (A) & $4.53 \pm 0.17$ & $233.01 \pm 0.78$ \\
Boiled (B) & $3.25 \pm 0.07$ & $202.23 \pm 0.25$ \\
Roasted (C) & $4.86 \pm 0.02$ & $210.95 \pm 0.78$ \\
Alkali treated (D). & $4.60 \pm 0.12$ & $206.71 \pm 0.07$ \\
't' value among maize samples & & \\
$\mathbf{A} \times \mathbf{B}$ & $15.43^{* *}$ & $49.44^{* *}$ \\
$\mathbf{A} \times \mathbf{C}$ & $(-) 4.75^{* *}$ & $46.85^{* *}$ \\
$\mathbf{A} \times \mathbf{D}$ & $(-) 1.48^{\mathrm{NS}}$ & $54.21^{* *}$ \\
$\mathbf{B} \times \mathbf{C}$ & $(-) 42.34^{* *}$ & $(-) 23.06^{* *}$ \\
$\mathbf{B} \times \mathbf{D}$ & $(-) 17.35^{* *}$ & $(-) 10.14^{* *}$ \\
$\mathbf{C} \times \mathbf{D}$ & $5.52^{* *}$ & $7.54^{* *}$ \\
\hline
\end{tabular}

Each value is the mean of six observations

${ }^{\text {NS }}$ Not significant

*Significant at $5 \%$ level of probability

**Significant at $1 \%$ level of probability

Table.2 Percentage change in zinc and phytic acid content in maize after processing as compared to control sample

\begin{tabular}{lcc}
\hline Maize grain sample & ZINC (\%) & PHYTIC ACID (\%) \\
\hline Boiled (B) & $28.25 \downarrow$ & $13.20 \downarrow$ \\
Roasted(C) & 7.28 & $9.46 \downarrow$ \\
Alkali treated (D) & 1.54 & $11.28 \downarrow$ \\
\hline
\end{tabular}

$\downarrow$ Indicates decreasing trend 
Table.3 Bio-availability of zinc in normal maize flour before and after processing

\begin{tabular}{|lc|}
\hline BIOAVAILABILITY OF ZINC & (Phytate : Zinc Molar Ratio) \\
\hline ControI(A) & 5.11 \\
Boiled (B) & 6.12 \\
Roasted (C) & 4.31 \\
Alkali Treated (D) & 4.47 \\
\hline Phytate/ zinc molar ratios & \\
Greater than 5 : Low zinc bio-availability & \\
Between 5-15 : Medium zinc bio-availability \\
Less than $5 \quad:$ Good zinc bio-availability \\
\hline
\end{tabular}

Figure.1 Percentage change in zinc and phytic acid content in maize after processing as compared to control sample

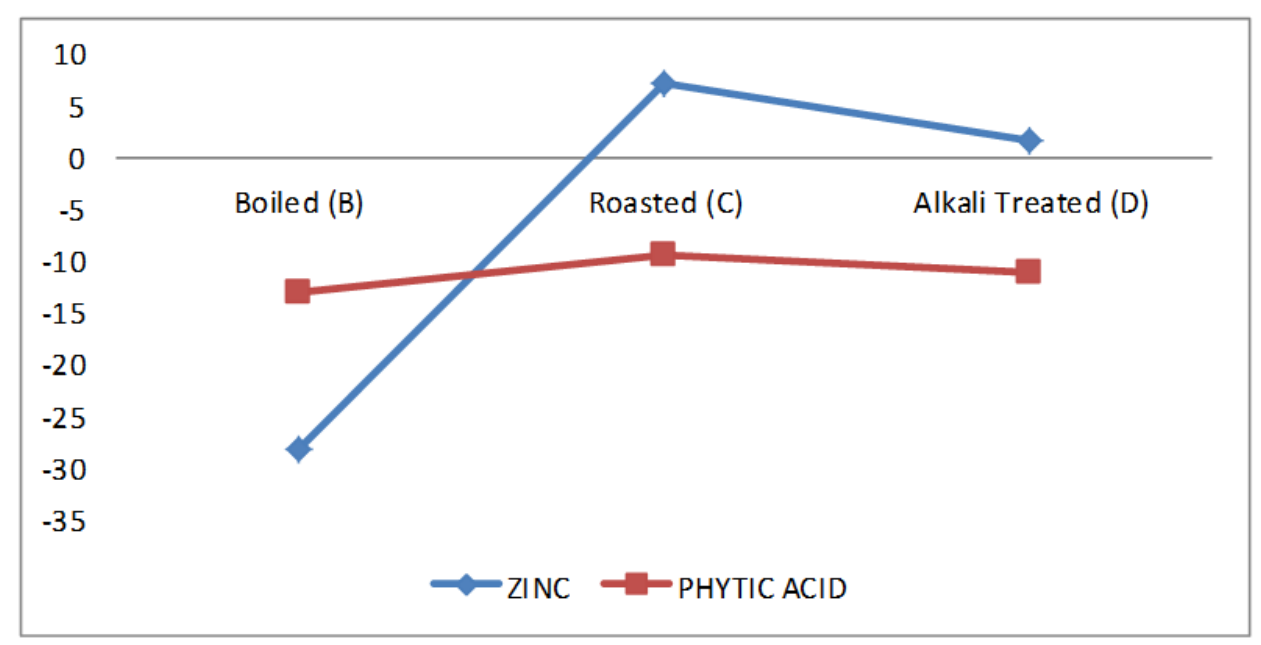

It was revealed from the Table that in the control maize sample the Phytate : Zinc molar ratio was found to be 5.11 . In the boiled maize sample, the ratio was 6.12 , in the roasted maize sample it was found to be 4.31 and in the alkali treated maize sample, it was found to be 4.47 .

It can be observed from the Table 3 that the Phytate: Zinc molar ratio in the roasted maize sample was the lowest (4.31) followed by alkali treated maize sample (4.47), control maize sample (5.11) and boiled maize sample (6.12).

This clearly shows that in maize flour, the control maize sample and the boiled maize sample had medium Zinc bioavailability whereas, the roasted maize sample and the lime treated maize sample had good Zinc bioavailability.

In conclusion, phytate: Zinc molar ratio in the roasted maize sample was the lowest (4.31) 
followed by alkali treated maize sample (4.47), control maize sample (5.11) and boiled maize sample (6.12). In maize flour, the control maize sample and the boiled maize sample had medium Zinc bioavailability whereas, the roasted maize sample and the lime treated maize sample had good Zinc bioavailability.

\section{References}

Bohn, L., Josefsen, L., Meyer, A.S. and Rasmussen, S. (2007). Quantitative analysis of phytate globoids isolated from wheat bran and characterization of their sequential dephosphorylation by wheat phytase. Journal of Agricultural and Food Chemistry, 55, 7547-7552.

Davies, N. T. and Reid, H. (1979). An evaluation of the phytate, zinc, copper, iron and manganese contents of, and zn availability from, soya-based textured vegetable- protein meat substitutes or meat extenders .The British journal of nutrition, 41, 579.

Hambidge, K.M. (1987). Zinc. In: Trace elements in human and animal nutrition. Mertz, W., 5th edn. Orlando, Florida, Academic Press, Inc, 1, pp.1-137.

Hurrell, R.F. (2004). Phytic Acid Degradation as a Means of Improving Iron Absorption. International Journal for Vitamin and Nutrition Research, 74, 445-452.

Li, C.Y., Park, D.S., Won, S.R., Hong, A.K.,
Ham, J.K., Choi, J.K. and Rhee, H.I. (2008). Food chemical properties of low-phytate rice cultivar, Sang-gol. Journal of Cereal Science, 47, 262-265. Lindsay, W.L. and Norvell, W.A. (1978). Development of DTPA soil test for $\mathrm{Zn}$, $\mathrm{Fe}, \mathrm{Mn}$ and $\mathrm{Cu}$. Soil Science Society of American Journal, 42, 421-428.

Norhaizan, M.E. and NorFaizadatul Ain, A.W. (2009). Determination of Phytate, Iron, Zinc, Calcium Contents and Their Molar Ratios in Commonly Consumed Raw and Prepared Food in Malaysia. Malasiyan Journal of Nutrition, 15(2), $213-222$.

Sandstrom, B. (1997). Bioavailability of zinc. European Journal of Clinical Nutrition, 51(S)1, S4-S8.

Schlemmer, U., Frølich, W., Prieto, R.M. and Grases, F. (2009). Phytate in foods and significance for humans: food sources, intake, processing, bioavailability, protective role and analysis. Molecular Nutrition and Food Research, 53(S2), S330-S375.

Snedecor, G.W. and Cochran, W.G. (1989). Statistical methods, eighth edition, lowa state university press.

Suri, D.J. and Tanumihardjo, S.A. (2016). Effects of Different Processing Methods on the Micronutrient and Phytochemical Contents of Maize: From A to Z. Comprehensive Reviews in Food Science and Food Safety _ Vol. 15.

\section{How to cite this article:}

Jati Heleena and Singh Usha. 2018. Effect of Changes in Zinc and Phytic Acid Content in Maize under Various Processes on Bioavailability of Zinc. Int.J.Curr.Microbiol.App.Sci. 7(12): 1715-1722. doi: https://doi.org/10.20546/ijcmas.2018.712.199 